\title{
Myanmar's military: Its power over business and human rights and the UN’s Guiding Principles
}

Edition 3, 2020

Professor Catherine Renshaw

DOI: 10.37839/MAR2652-550X3.10

On 5 August 2019, the United Nations Independent International Fact-Finding Mission on Myanmar (the 'Fact Finding Mission') submitted a report to the Human Rights Council on the economic interests of Myanmar's military.

The report stated that two powerful military conglomerates, Myanmar Economic Holdings Limited (MEHL) and Myanmar Economic Corporation (MEC)-which own businesses across diverse sectors of the economy from construction and gem extraction to manufacturing, insurance, tourism and banking-were directly involved in gross violations of international human rights law and serious violations of international humanitarian law.

Violations included forced labour and sexual violence in mining enterprises in Kachin and Shan States. The report also found that private companies with enduring links to the military were financing development projects in northern Rakhine, thereby consolidating the consequences of the military's persecution of the Rohingya. The projects were carried out under the Union Enterprise for Humanitarian Assistance, Resettlement and Development in Rakhine (UEHRD) which is chaired by State Counsellor Aung San Suu Kyi.

The United Nations Guiding Principles on Business and Human Rights encourage states to take additional steps to protect against human rights abuses by business enterprises that are owned or controlled by the State, including, where appropriate, 
by requiring human rights due diligence. The Principles also require States to provide guidance to business enterprises on how to respect human rights throughout their operations.

The evidence presented by the Fact-Finding Mission is an extreme example of how Myanmar is failing on both these counts.

At present there is little prospect of containing 'military capitalism'. The military (known as the Tatmadaw) has a central political role under Myanmar's constitution and is fiscally and administratively autonomous. The Constitution provides that $25 \%$ of members of state and federal parliaments must be serving army officers appointed by the commander-in-chief, and that the Constitution cannot be amended without the approval of more than $75 \%$ of Parliament.

\section{Other economic actors pursuing a business and human rights agenda}

Myanmar emerged from almost 20 years of direct military rule in 2011, at the same time as the UN Human Rights Council unanimously adopted the Guiding Principles on Business and Human Rights and its economic potential is significant. It is rich in natural resources (gas, teak and jade) and is located between China and India, on one of the world's major trading routes. It also has a young population.

Following elections in 2010 and Aung San Suu Kyi's entry into parliament in 2012, most Western sanctions were removed. In 2016, Myanmar recorded the fastest GDP growth of any country in Asia and was hailed as the 'next Vietnam', capable of realising $10 \%$ growth. A key priority for the new regime was obtaining foreign investment to promote long-term growth and development; and diversifying sources of foreign direct investment to reduce over-reliance on China. The Guiding Principles aligned with the economic strategy of Myanmar's major democratic political party the National League for Democracy, which took power in elections in 2015 on a 
platform of 'macroeconomic stabilisation, long-term growth and development, economics for democracy and national economic sovereignty'.

For some international investors and domestic entrepreneurs, democratic transition represented an opportunity to employ best practice business standards to achieve sustainable, inclusive and peaceful development. Organisations such as the Myanmar Centre for Responsible Business were established, committed to the process of engaging government and private companies in changing the culture of business through capacity building, advice and support on disclosure and good practice.

There have been some notable successes. Myanmar Petroleum Resources Limited (MPRL) introduced a Guiding Principles compatible 'operational grievance mechanism' which has been a model for inspiring other businesses. For some private companies, in the aftermath of decades of military rule and cronyism, the business and human rights agenda promised a remedy for 'corruption fatigue'. Some studies report 'extraordinarily high levels' of awareness of Corporate Social Responsibility and Sustainable Development Goals among Myanmar's domestic businesses. For Western investors, the Unocal litigation in the 1990's provided a cautionary tale about the problems of investing without paying due attention to human rights. In 1996, Burmese villagers sued Unocal in the federal court of the United States, accusing the company of forced labour, murder, rape and torture in the construction of a gas pipeline in Myanmar. The case settled after almost a decade of litigation.

\section{Significant challenges to the development of a business and human rights agenda}

One challenge is the fact of military power and the extent of the military's economic influence, coupled with the absence of civilian oversight of the military's corporate activities. The military's influence will persist after the 2020 elections, because Myanmar's constitution entrenches the military in the political life of the state and 
the constitution cannot be changed without the agreement of the military.

Another challenge is China, which shares the 2,000 kilometre border in Myanmar's north. China is and will remain Myanmar's largest investor. The discourse of responsible business extends very thinly, if at all, to China's many massive infrastructure, mining and energy projects in Myanmar: dams, gas pipelines and special economic zones that form a key part of China's Belt and Road Initiative.

There is also the challenge from the opposite direction, stemming from the tsunami of well-intentioned external advisors who, after transition, flooded Myanmar with workshops, agendas, promotional activities and the multitude of partially competing discourses and initiatives aligned to different agendas: the Sustainable Development Goals; the UN's Guiding Principles; Corporate Social Responsibility; and the UN Global Compact. In 2016 there was a well-publicised conflict between the United Nations Development Program (UNDP) and United Nations Office of the High Commissioner for Human Rights, about whether to pursue a strategy of engagement or condemnation in relation to the rapidly deteriorating situation of the Rohingya in Rakhine state.

What emerges from all this, in terms of the future of the Guiding Principles in Myanmar, is a complex, fragmented and shifting picture. The military and Chinese investors, the two most powerful economic actors in the country, have not engaged with the business and human rights agenda. On the other hand in 2018, Myanmar's National Human Rights Commission, in cooperation with the UNDP, committed itself to exploring with relevant ministries what the 'duty to protect' in the Guiding Principles means in the context of their mandates. The major democratic political party, the National League for Democracy (NLD), together with local entrepreneurs and Western investors, are keen to position themselves as part of the changing culture of business practice in Myanmar.

But Myanmar does not currently have a National Action Plan. A National Baseline Assessment has not yet been carried out. Myanmar does not possess a Ministry of 
Justice that could shepherd a program of human rights compliant regulatory reform.

The most significant point, perhaps, is that even if such a program were to be pursued, the rule of law is still weak in Myanmar and ensuring compliance would be difficult.

\section{Political transition and progress}

The issues arising from the nature of Myanmar's transition from military to civilian government, in terms of business and human rights, concern both state responsibility to protect and corporate responsibility to respect. Attempts to reform the jade industry provide an insight into some of the challenges. The jade industry, thought to account for half of Myanmar's gross domestic product, has long been the Tatmadaw's most lucrative sector. Only a small fraction of jade is officially sold and taxed through the government-run Myanmar Gems Enterprise which sits within the Ministry of Natural Resources and Environmental Conservation. The rest is smuggled into China. Most mining is conducted through informal consortiums that include companies with military connections or in which the Tatmadaw has major holdings. MEHL and MEC are major players in the industry. The Fact Finding Mission identified MEHL and MEC and 26 of their subsidiaries as having numerous licenses for jade and ruby mining in Kachin and Shan States.

In 2016, the NLD promised to tackle the serious issues associated with the jade industry. A number of measures were attempted. Through the Myanmar Gems Enterprise, the government requested that environmental management plans be prepared to improve environmental and social management of existing and future jade mining. However, there was limited involvement by local authorities and an absence of mechanisms for implementation or accountability. There was secrecy (or confusion, or both) about which mining companies were associated with which concessions, and serious difficulties in determining which companies were responsible for the management and monitoring of environmental and social impacts 
of different concessions. Old practices continued and the military and its related companies were the benefactors. In 2019 a new gemstone law was promulgated which it has yet to be implemented.

The human rights consequences of regulation failure are severe. Mining practices in Myanmar are environmentally devastating and have destroyed watercourses, sensitive vegetations, villages and settlements, cultural heritage sites. They are also notoriously unsafe. After the democratisation process began in 2011, jade mining became more frenetic and less regulated. The removal of sanctions meant that local companies could import heavier industrial equipment from international companies such as Caterpillar, Volvo, Komatsu and Liebherr, to dig and haul larger amounts of soil from more extensive sites. As supplies of surface jade were exhausted, deeper mining began to take place without systematic explorations to determine the location, depth and thickness of the jade formations. In 2015, more than 120 people died beneath a mound of mining waste. Most mines are officially closed in the rainy season, but thousands of yemase (illegal workers) continue to scour the area for jade. On 22 April 2019, another landslide killed more than 50 people. On 2 July 2020, at the Wai Khar jade mine in Kachin state, more than 150 miners died when an open pit jade mine collapsed, burying them. The Myanmar National Human Rights Commission employed the language of the Guiding Principles when it criticized the mines' owners in the wake of the disaster: 'it defies understanding [that mining companies] have not bothered to carry out human rights due diligence and the necessary risk assessment despite making billions of dollars a year'.

Extractive industries and the jade trade also provide the reason for-and fund-the continuation of conflict between the military and ethnic armed organisations in mineral-rich states such as Kachin. The military's historical priority of preserving national unity is overlaid with the substantial economic interests of the military and their associates, and of the Myanmar and Chinese businesses who seek to preserve their investments. In Kachin, a peace deal between the military and the Kachin Independence Organisation (KIO) in 1994 brought with it the potential for local Kachin political leaders to make large amounts of money. Local Kachin strongmen 
exploited the natural resources of the state in collaboration with the Tatmadaw and Chinese companies. The business methods of the KIO were often indistinguishable from those of the Tatmadaw, and included cronyism, land-grabbing, exploitation and tactics of terror against local populations. There was little consultation between KIO leaders and the people about economic decisions that affected their lives.

Democratisation imperiled the profits of both the Tatmadaw and the KIO. The 14year ceasefire between the Tatmadaw and the Kachin Independence Army (KIA) came to an end in 2010 when the KIA refused to accede to a request that it transform its military forces into a Border Guard Force under the control of the Tatmadaw. President Thein Sein's orders that the army not launch attacks on ethnic armed groups in northern Kachin State were defied. From 2011, the Tatmadaw intensified attacks on KIA positions, displacing hundreds of thousands of civilians. The civil war in Kachin still continues. Research carried out by Christensen, Nguyen and Sexton found that Myanmar's military selectively stoked conflict to retain its stake in the country's jade-mining sector. Global Witness reported in 2015:

'As with war economies the world over, genuine peace and outright war are the main enemies of the military entrepreneurs in the jade mining areas of Kachin state. Far preferable are the grey areas between that justify the deployment of troops needed to intimidate and extort but do not demand much actual fighting.'

\section{China's Influence in Myanmar}

China's 2019 commitment before the Universal Periodic Review-an official process which involves a review of the human rights records of all UN Member States-was to:

'Promote measures that ensure that development and infrastructure projects inside and outside of its territory are fully consistent with human rights and respect the environment and natural resource sustainability, in line with national and international law and with the commitments from the 2030 Agenda for Sustainable 
Development' and 'Consider the possibility to establish a legal framework to guarantee that the activities carried out by industries subject to its jurisdiction do not undermine human rights abroad'.

At present, however, Chinese companies operating in Myanmar do not utilise the framework of the Guiding Principles on Business and Human Rights.

For China, Myanmar has geo-strategic importance as a trading route to the Bay of Bengal and the Indian Ocean; and Myanmar's hydro-power potential represents the opportunity to shore up China's energy security, particularly in underdeveloped Yunnan province. For Myanmar, China is a source of funding for desperately needed infrastructure projects, which the Chinese provide without human rights conditionalities. In 2018 China cemented its economic interests in Myanmar by signing a Memorandum of Understanding with Myanmar's government to build the China-Myanmar Economic Corridor (CMEC), a major infrastructure project of 1700 $\mathrm{km}$ of highways and railways that will begin in Kunming and extend to the deep water port at Kyaukphyu in Rakhine state. The CMEC will intersect with Myanmar's economic centres of Mandalay in central Myanmar, Yangon in the South and the Kyaukphyu Special Economic Zone in the West.

On one level, the relationship between Myanmar and China is uncomplicated. Myanmar needs China's investment in infrastructure and China needs Myanmar's access to the sea and energy supplies. China has protected the relationship by defending Myanmar in international forums like the Security Council. Within Myanmar, the relationship is fraught with anxieties. The decision of Myanmar's generals to allow democratisation stemmed in part from the desire to reduce dependence on China by creating conditions that would allow an opening up to the West. Within Myanmar there are concerns at all levels of society about sovereignty in terms of economic independence and the level of debt owed to China. There are concerns, as well, about the long-term environmental damage caused by some of China's massive energy and infrastructure projects. In ethnic states, there are tensions over the management and profit distribution from Chinese involvement in 
mining, energy, timber and transport.

In 2011, sensitivities within Myanmar about the scale and impact of Chinese infrastructure projects crystallised around the massive Myitsone Dam project in Kachin state. The N'mai Hka and Mali Hka rivers converge at Myitsone in Kachin to form the Irrawaddy, the largest waterway in Myanmar. In 2009, Myanmar's (then military) government agreed to the construction of a \$US3.6 billion dam at Myitsone, with $90 \%$ of the resulting electricity to be exported to China. China Power Investment Corporation, which was to cover $80 \%$ of the cost of construction, prepared an internal report which highlighted possibilities of disruption to the river flow, disappearance of a migratory fish species and the flooding of 26,238 hectares of rain forests. In 2011, parts of the report were leaked to opponents of the dam and there were widespread protests against its construction.

In September 2011, President Thein Sein announced that the government would suspend its work at least until 2015. The decision was interpreted as a sign that the new government of Myanmar was reconsidering its close relation with China. In 2016, with the support of the International Finance Corporation, Myanmar's government commissioned a strategic environmental assessment on all hydropower projects in Myanmar. The report recommended against building the Myitsone dam and other hydropower projects on the mainstream of Myanmar's five major rivers. It is unclear, however, whether the Ministry of Electricity and Energy accepts the report's findings. In July 2018, the Ministry commenced work on a new hydropower policy, with assistance from the Chinese government. The fate of the Myitsone dam is still unclear.

\section{There is still, in the words of the Fact- Finding Mission, 'a pervasive culture of}




\section{impunity'}

The most considered and influential civil society actors in the business and human rights space are not calling for the creation of National Action Plans that align with the UNGPs. Instead, they are calling for basic effective regulation of industry and the rule of law. Yet it would be a mistake to take the view that the process of democratisation in Myanmar has failed to bring about significant change to business practices. A degree of change has been wrought by top-down action-through government reform-and from the bottom up, as civil society actors find new (though contested) spaces to challenge the actions of corporations.

One example of top-down reform is the government of Myanmar's commitment to implement the Extractive Industry Transparency Initiative (EITA). Myanmar was accepted as an EITI candidate in 2014. Myanmar's first EITI report disclosed that more than $50 \%$ of revenues from State Owned Enterprises, primarily in the extractive sector, were kept in separate "Other Accounts" instead of being transferred to the State Budget.

The 2019 EITI report shows that in the fiscal year 2017-2018, Myanmar's largest operating SOE, Myanmar Oil and Gas Enterprise, had an "Other Account" with a closing balance of \$USD4.6 billion, more than six times the total revenue collected from oil and gas companies in the same period. Rules for retention and spending around "Other Accounts" are oblique. In 2019, the government issued a directive that "Other Accounts" were to be abolished and that from July 2019, all revenues from SOEs were to be transferred to the State Budget. The directive was framed as an essential part of Myanmar meeting the Sustainable Development Goals. In relation to change from the bottom up, Myitsone Dam stands as a strong example of the successful activism of coalitions of well-networked civil society groups.

Between government and civil society there are creative and agile networks dedicated to improving business practices. The Myanmar Coalition for Transparency, for example, which in 2014 became the Myanmar Alliance for Transparency and 
Accountability, is a nationwide umbrella organisation of 449 civil society networks and individual members from all states and regions, with the objective of advocating for transparency and accountability by government, elected representatives, companies, donors and civil society to promote freedom of public participation and scrutiny of Myanmar's legal frameworks and guidelines relating to resources. It is also a positive development that reliable information about how Myanmar's governance promotes or impedes the protection of human rights is now readily available. MCRB's Sector Wide Impact Assessments, for example, provide analyses of the actual and potential human rights impacts of particular sectors (Oil and Gas; Tourism; ICT and Mining). The Assesments are based on the UNGPs and other international standards.

Despite these advances, Myanmar still tests the logic that underpins the United Nations Guiding Principles on Business and Human Rights. The 'protect, respect and remedy' framework assumes productive interaction between:

- a state that legislates and enforces rules that respect human rights;

- empowered stakeholders able to employ social and legal compliance mechanisms, advocacy and strategic litigation;

- a corporate governance system which internalises pressure and expectations of the other two systems.

In Myanmar, in relation to many sectors of the economy, the logic fails at the first hurdle. The state does not fulfil its obligation to protect.

Myanmar stands as an example of the difficulties of employing the UNGPs in contexts where democratic transition is not consolidated and the states capacity to control corporate actors is weak.

Image: A jade mine in Myanmar. Credit: Hosana Chay, NRGI Myanmar, The EITI/Flickr 